\title{
Simultaneous transfemoral transcatheter mitral and tricuspid valve edge-to-edge repair (using MitraClip system) completed by atrial septal defect occlusion in a surgically inoperable patient. First-in-human report
}

\author{
Marek Kowalski ${ }^{1}$, Norbert Franz ${ }^{1,2}$, Frank Ritter ${ }^{1}$, Steffen Hofmann ${ }^{3}$, Chourok Stabel-Mahassine ${ }^{3}$, \\ Henning Warnecke ${ }^{2,3}$, Joachim Thale ${ }^{1}$ \\ ${ }^{1}$ Department of Cardiology, Schuechtermann-Klinik, Bad Rothenfelde, Germany \\ 2University Witten/Herdecke, Germany \\ ${ }^{3}$ Department of Cardiac Surgery, Schuechtermann-Klinik, Bad Rothenfelde, Germany \\ Kardiochirurgia i Torakochirurgia Polska 2015; 12 (4): 295-297
}

\begin{abstract}
Transcatheter transfemoral mitral valve repair using the MitraClip system (Abbott Vascular, USA) is used in high-risk or inoperable patients with severe mitral regurgitation. We report the first-in-human simultaneous transfemoral clipping of the mitral and tricuspid valve completed by occlusion of an atrial septal defect (ASD). The procedure was performed in an 84-year-old patient in October 2015. After effective reduction of mitral and tricuspid regurgitations using the MitraClip system a PFO Occluder (St. Jude Medical, USA) was implanted. Transfemoral simultaneous mitral and tricuspid valve repair using the MitraClip system with ASD occlusion seems to be an effective therapy for high-risk or inoperable patients.

Key words: MitraClip, tricuspid valve.
\end{abstract}

\section{Introduction}

Transcatheter mitral valve edge-to-edge repair using the MitraClip system (Abbott Vascular, USA) has been used for several years in high-risk or inoperable patients with isolated severe mitral regurgitation [1-3]. To our knowledge a simultaneous transfemoral clipping of the mitral and tricuspid valve completed by occlusion of an atrial septal defect has not been performed so far. Therefore this firstin-human intervention is hereby reported.

\section{Case report}

A 84-year-old female patient with a history of repeated left and right heart decompensation suffered from severe dyspnea on admission (New York Heart Association functional class III), lower leg edema, bilateral pleural effusions and a stage III chronic kidney disease. Echocardiography

\section{Streszczenie}

Przezcewnikowa implantacja zapinki MitraClip (Abbott Vascular, USA) jest stosowana w leczeniu pacjentów wysokiego ryzyka z ciężką niedomykalnością zastawki mitralnej. Autorzy przedstawiają pierwszą na świecie jednoczesną implantację zapinki MitraClip na zastawce mitralnej i trójdzielnej, włącznie z zamknięciem jatrogennego ASD (PFO Occluder), wykonaną przez żyłę udową u 84-letniej pacjentki w październiku 2015 r. Słowa kluczowe: MitraClip, zastawka trójdzielna.

showed a moderate to severe recurrent mitral regurgitation after prior successful MitraClip implantation several months ago. In addition a residual ASD with significant leftto-right-shunt and severe tricuspid valve regurgitation with tethered leaflets were found. The left ventricular ejection fraction was reduced (35\%). The right ventricular function was not compromised. The systolic pulmonary artery pressure was slightly elevated $(40 \mathrm{mmHg})$. As a result of the heart team discussion the patient was declared as surgically inoperable.

The procedure was performed on October 20, 2015 under general anaesthesia using two- and three-dimensional transesophageal echocardiographic (TEE) (iE 33, Philips Healthcare, Netherland) and fluoroscopy guidance (Axiom Artis Zeefloor AXH 1604, Siemens, Germany). After reaching the left atrium via the preexisting ASD a second MitraClip was fixed in the mitral valve next to the first one

Address for correspondence: Marek Kowalski, MD, PhD, Schüchtermann-Klinik, Ulmenallee 5-11, 49214 Bad Rothenfelde, Germany, phone: 0049 542464130023, e-mail: MKowalski@schuechtermann-klinik.de 

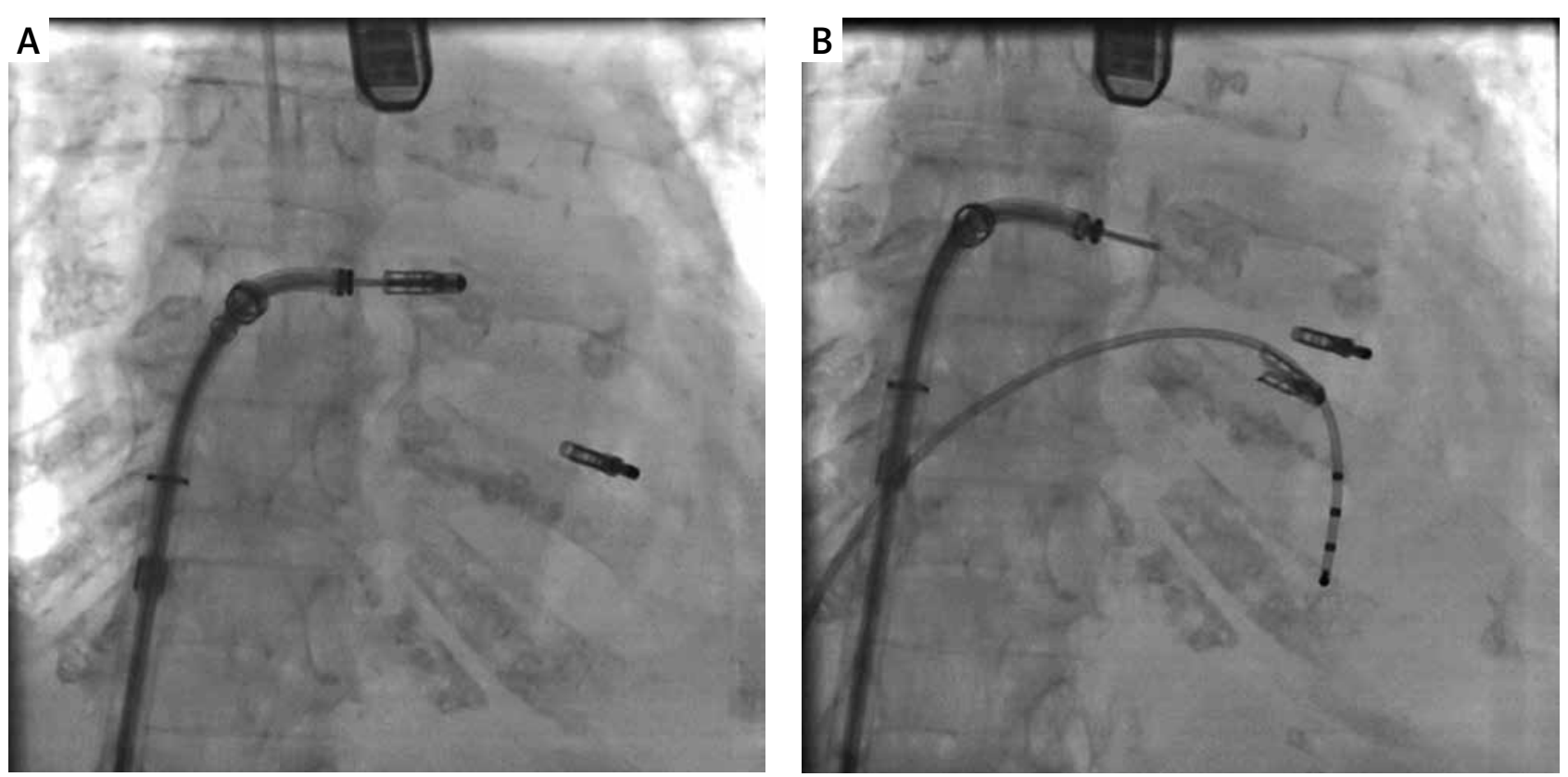

Fig. 1. A) X-ray $\left(\mathrm{RAO} 0^{\circ}\right.$ ) before repeated MitraClip implantation: steerable Guide and Clip delivery system positioning in left atrium, clip arms closed. Transesophageal echocardiographic (TEE) probe in position. B) X-ray (RAO $0^{\circ}$ ) after successful second MitraClip deployment: clip delivery system removed into the left atrium, two clips in the mitral valve. Transesophageal echocardiographic probe in position. Temporary pacing lead in right ventricle

(Fig. 1A-B). The MitraClip procedure was performed transfemorally according to the Instructions for Use of the MitraClip system (FDA, USA). After reposition of the steerable guiding catheter in the right atrium a new clip delivery system was introduced into the guiding catheter, but temporarily was left inside. Then the guiding catheter was angulated slightly in "plus" and "anterior" directions to po-

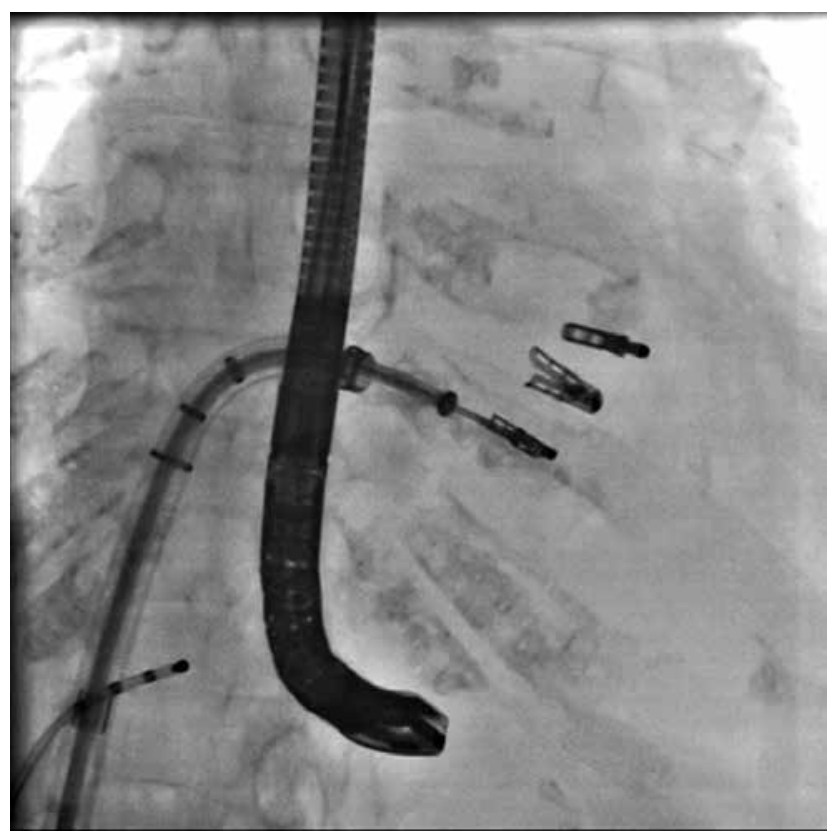

Fig. 2. X-ray $\left(\mathrm{RAO} 0^{\circ}\right)$ before edge-to-edge repair of tricuspid valve using MitraClip system: steerable Guide and Clip delivery system positioning in right atrium, clip arms open. Transesophageal echocardiographic (TEE) probe in position. Temporary pacing lead removed into right atrium sition the guiding catheter vertically to the tricuspid valve. The next step of the maneuver consisted of advancing the MitraClip device into the right atrium, opening both arms, centering and advancing the system into the right ventricle (Fig. 2). By retracting the MitraClip device both leaflets (anterior and septal) were grasped and closed to coapt the tricuspid leaflets. After an effective reduction of tricuspid regurgitation had been achieved, the clip was deployed (Fig. 3A-B). The clip delivery system and guiding catheter were withdrawn. Finally a $25 \mathrm{~mm}$ PFO Occluder (St. Jude Medical, USA) was successfully implanted to close the atrial septal defect, using the MitraClip guiding catheter (Fig. 4).

Reconstruction of the two- and three-dimensional transesophageal echocardiographic dataset documented a significant echocardiographic improvement: there was an effective reduction of both mitral regurgitation (vena contracta area at baseline $0.395 \mathrm{~cm}^{2}$, after procedure $0.17 \mathrm{~cm}^{2}$ ) and tricuspid regurgitation (vena contracta area at baseline $1.03 \mathrm{~cm}^{2}$, after procedure $0.66 \mathrm{~cm}^{2}$ ). The atrial septal defect was completely closed by the occluder.

The patient tolerated the simultaneous procedure very well and was discharged 4 days after the implantation.

\section{Discussion}

High-risk or inoperable patients with severe mitral and tricuspid regurgitation in combination with ASD are seriously medical challenging. New percutaneous transcatheter methods represent potential technologies to treat these patients with good results. Especially the treatment of the mitral valve with the MitraClip system is well established.

This first-in-human report describes a simultaneous transfemoral transcatheter edge-to-edge repair of both the 

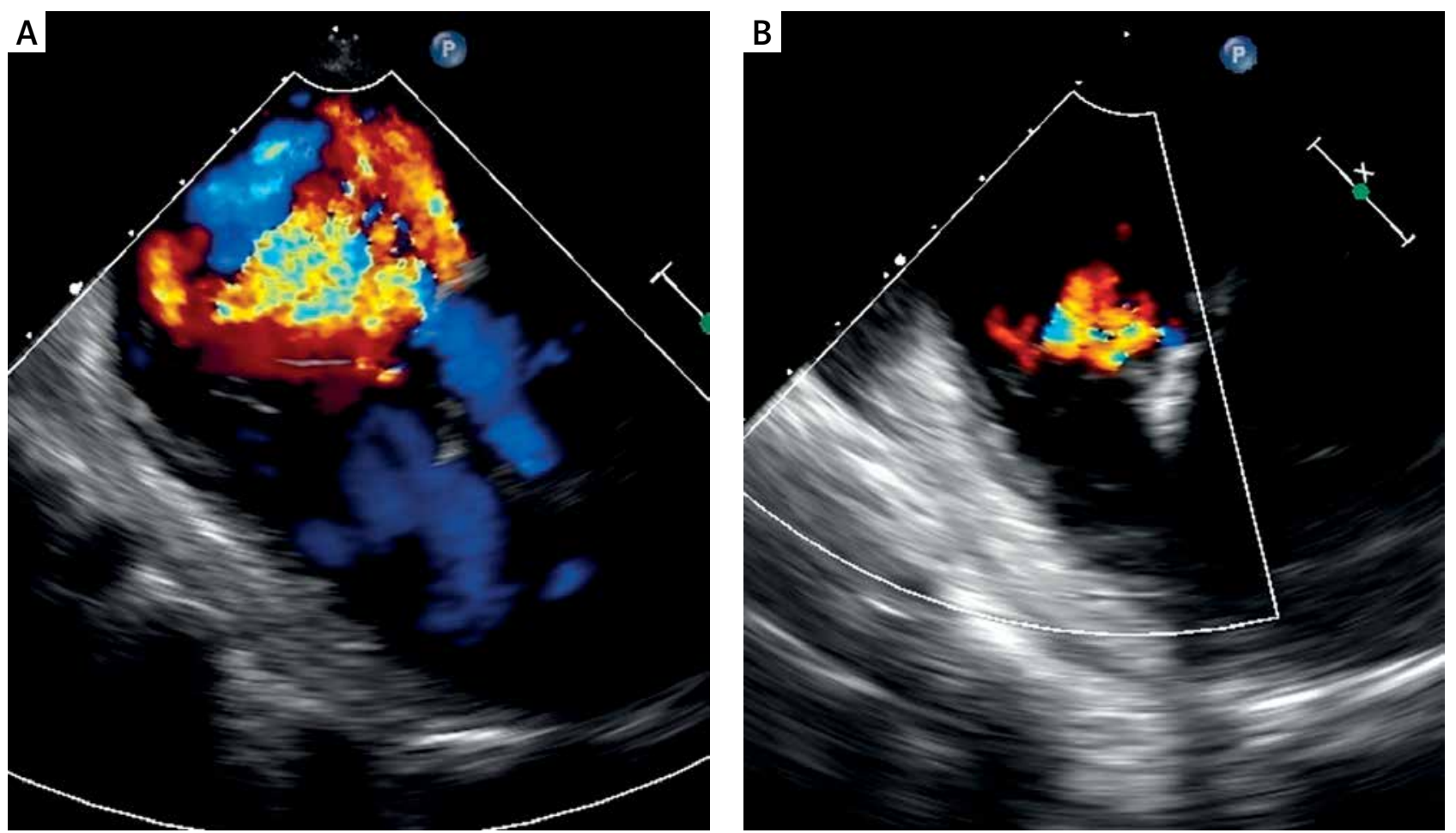

Fig. 3. A) Two-dimensional transesophageal echocardiography (short axis view with color Doppler) before tricuspid valve repair using MitraClip system: severe tricuspid regurgitation. B) Two-dimensional transesophageal echocardiography (short axis view with color Doppler) after tricuspid valve repair using MitraClip system: moderate tricuspid regurgitation

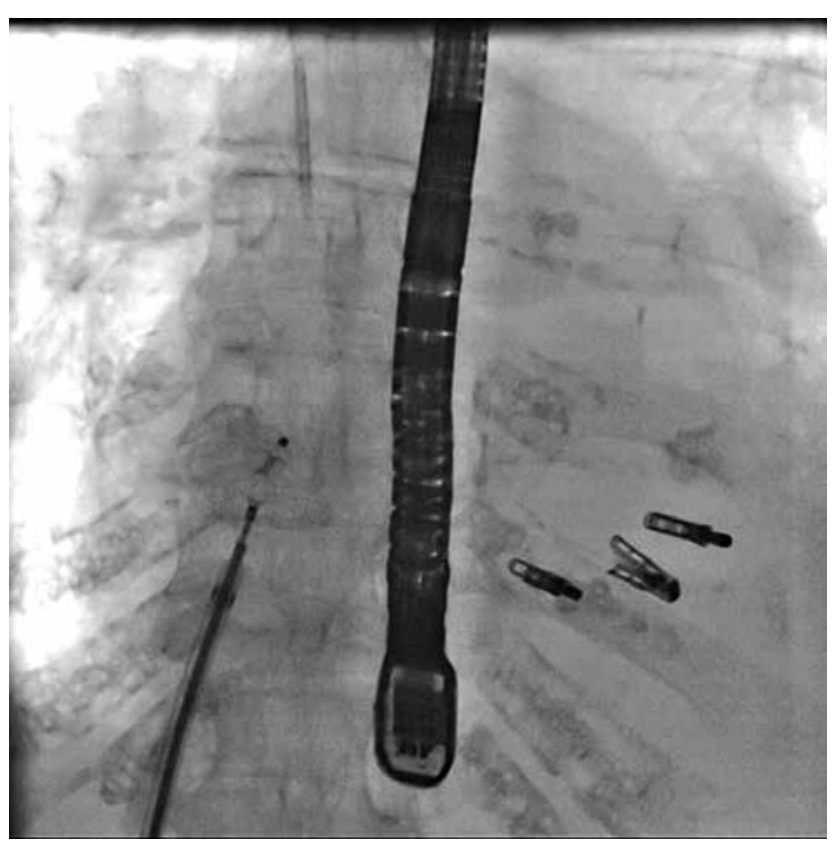

Fig. 4. X-ray $\left(\mathrm{RAO} 0^{\circ}\right)$ atrial septal defect (ASD) closure using a PFO Occluder. Clips from right to left: two clips in mitral valve, one clip in tricuspid valve. Transesophageal echocardiographic (TEE) probe in position

mitral and tricuspid valve using the MitraClip system completed by occlusion of an atrial septal defect using the PFO Occluder. Two- and three-dimensional transesophageal echocardiography with multiplane imaging and fluoroscopy were necessary for the precise navigation and placement of the MitraClip and PFO Occluder. An effective reduction of mitral and tricuspid regurgitation with successful occlusion of the ASD was achieved.

In conclusion, it has been shown that transfemoral simultaneous ("one approach") mitral and tricuspid valve repair using the MitraClip system with ASD occlusion could be a feasible, safe and well-tolerated therapy for high-risk or inoperable patients, who are non-responders to conservative medical treatment.

\section{Disclosure}

Authors report no conflict of interest.

\section{References}

1. Feldman T, Kar S, Rinaldi M, Fail P, Hermiller J, Smalling R, Whitlow PL, Gray W, Low R, Herrmann HC, Lim S, Foster E, Glower D; EVEREST Investigators. Percutaneous mitral repair with the MitraClip system: safety and midterm durability in the initial EVEREST (Endovascular Valve Edge-to-Edge REpair STudy) cohort. J Am Coll Cardiol 2009; 54: 686-694.

2. Feldman T, Foster E, Glower DD, Kar S, Rinaldi MJ, Fail PS, Smalling RW, Siegel R, Rose GA, Engeron E, Loghin C, Trento A, Skipper ER, Fudge T, Letsou GV, Massaro JM, Mauri L; EVEREST II Investigators. Percutaneous repair or surgery for mitral regurgitation. N Engl J Med 2011; 364: 1395-1406.

3. Gaemperli O, Moccetti M, Surder D, Biaggi P, Hurlimann D, Kretschmar O, Buehler I, Bettex D, Felix C, Luscher TF, Falk V, Grunenfelder J, Corti R. Acute haemodynamic changes after percutaneous mitral valve repair: relation to mid-term outcomes. Heart 2012; 98: 126-132. 